\title{
Obstacles of Financing Small Projects by Jordanian Commercial Banks
}

\author{
Abedalfattah Zuhair Al-abedallat ${ }^{1}$, Naseem M Aburuman ${ }^{1}$, Hamdan Moh' D Al - Hiyasat ${ }^{2}$, Belal Rabah Taher \\ Shammout ${ }^{1}$ \\ ${ }^{1}$ Department of banking and finance ,Faculty of Business and Finance, The World Islamic Sciences \& Education \\ University, Jordan P.O. Box 1101 Amman 11947, Jordan \\ ${ }^{2}$ Department of accounting, Faculty of Business and Finance, The World Islamic Sciences \& Education \\ University, Jordan P.O. Box 1101 Amman 11947, Jordan
}

Correspondence: Abedalfattah Zuhair Al-abedallat, Department of banking and finance ,Faculty of Business and Finance, The World Islamic Sciences \& Education University, Jordan P.O. Box 1101 Amman 11947, Jordan.

Received: February 16, 2017

Accepted: March 20, $2017 \quad$ Online Published: April 10, 2017

doi:10.5539/ibr.v10n5p13

URL: https://doi.org/10.5539/ibr.v10n5p13

\begin{abstract}
The small projects sector suffers from many constraints, especially in terms of the financial side due to weakness in the finance, the problem of the study occurs based on the presence of obstacles in financing small projects by Jordanian Commercial Banks (Banking Obstacles, Small Projects Obstacles, and Governmental Obstacles). Thus, the study seeks to identify those obstacles, and it founded there is a significant statistical impact of the obstacles (Banking obstacles, Small projects Obstacles, Governmental obstacles) on the financing of small projects by Jordanian commercial banks. Also, there is a good statistical relationship between the obstacles (Banking obstacles, Small projects Obstacles, Governmental obstacles) and the financing of small projects by Jordanian commercial bank. The study recommended that the central bank should make laws that force banks to set aside a portion of the loans portfolio to small projects. Also, there is a need for the government to provide support to small projects, specifically in the training of the human resources and in the making of an economic feasibility study.
\end{abstract}

Keywords: small projects, banking obstacles, small projects obstacles, governmental obstacles, Jordanian commercial bank

\section{Introduction}

Small projects play an important role in the economy of nations due to its leading role in the provision of varied work opportunities. Thus, it is the best way to foster economic development and social justice throughout the world. It works by creating jobs and solving the problem of unemployment. In addition, the reduction of immigration also increases the gross domestic product. Therefore, SMEs is the backbone of the economy in various countries around the world.

The concept of small projects differs from one country to another according to the different possibilities of economic and social conditions. However, there is an agreement among economists on the importance of this sector. This agreement forms the base of the economy in developed countries. The engine of the economy in developing countries is the sector which employs a large proportion of employment, and the sector which is characterized by economic diversification. Furthermore, it contributes to a good percentage of the gross domestic product.

Subsequently, this sector suffers from many constraints, especially in terms of the financial side due to weakness in the finance. Thus, this sector relies majorly on banks. Also, the holders of small projects mostly do not have creditability. As a result, there is difficulty in obtaining financing. Additionally, received funding can be costly and it can affect the chances of success.

The current target of most banks is the rich, and they focus on the financing of major projects. Also, they turn a blind eye to the financing of small projects because they carry a higher risk

The problem of the study occurs based on the presence of obstacles in financing small projects by commercial banks. Thus, the study seeks to identify those obstacles, the most important solutions to the problems, and aims at making appropriate recommendations. 


\section{Study Objectives}

The objectives of the study can be obtained by answering the following questions:

1. What is the reality of small projects in Jordan?

2. What is the size of finance for small projects in Jordan?

3. What is the importance of small projects in development?

4. What are the obstacles to the financing of small projects by the bank in Jordan?

5. What are the solutions to these obstacles?

\section{Study Framework and Hypotheses}

To study the Obstacles of financing small projects, the model below was constructed as follows:

\begin{tabular}{|c|c|}
\hline \multirow[t]{2}{*}{ Dependent Variable } & Independent \\
\hline & Banking obstacles \\
\hline $\begin{array}{l}\text { Financing the } \\
\text { Small Projects }\end{array}$ & Small projects Obstacle \\
\hline & Governmental obstacles \\
\hline
\end{tabular}

Figure 1. Study framework developed by the researcher

In studying the obstacles of financing small projects in the Jordanian Commercial Banks, the following hypotheses were built:

Ho1 - There is no significant statistical impact of the obstacles (Banking obstacles, small projects obstacles, Governmental obstacles) on the financing of small projects at $\mathrm{p} \leq 0.05$.

However, it consists of the followings sub-hypothesis:

Ho1-1 - There is no significant statistical impact of the Banking obstacles on the financing of small projects at $\mathrm{p}$ $\leq 0.05$

Ho1-2 There is no significant statistical impact of Small projects Obstacles on the financing of small projects at $\mathrm{p} \leq 0.05$

Ho1-3 - There is no significant statistical impact of the Governmental obstacles on the financing of small projects at $\mathrm{p} \leq 0.05$

\section{The Theoretical Framework}

\subsection{Concept}

The number of banks in Jordan is twenty-six which are distributed as follows: 13 Jordanian commercial banks; 9 foreign commercial banks; 3 Jordanian Islamic banks which include the Islamic International Arab Bank, Jordanian Dubai Islamic Bank, and the Jordanian Islamic Bank; and 1 foreign Islamic bank known as AL-Rajhi Bank (The Annual Report of the Central bank of Jordan, 2015).

The Arab Bank which is one of the oldest banks in Jordan was established in 1930. However, this was followed by the Alahli Bank which started in 1956. Thus, the Jordanian banks provide banking services allowed by law. Furthermore, it also considers the credit facilities of the most important services provided by the banks and which is the most profitable (Abdullah \&Trad, 2006).

There are several definitions for small projects which are as follows: They are projects or businesses with fewer than five workers and are approved by the Statistics General Department and the Social Security Corporation in Jordan division. On the other hand, the Ministry of Industry and Trade Jordanian stated that the project which employs a number of workers between 5-19 is a small project. In the United States, a project, which has a number of workers between 5-200, is considered as a small project. In addition, the European agency shows that a project whose number of workers is between 10-99 workers is considered as a small project.

However, several criteria to classify small projects can be divided into: 
1-Quantitative Criteria: These standards are based on the number of employees, capital, the value of assets, and the value of sales; however, the number of employees is regarded as the most common standard.

Subsequently, contrasting the use of these standards for countries is dependent on technological progress and the standard of living and the technological progress.

2. The Quality Standards and the Most Important of these Criteria:

A- Needed finance for the project.

B- Operations are in specific geographic area.

C- The size of institutions is relatively small compared with other institutions in the industrial field

\section{Small Projects Characteristics}

1- Centralization: The small-sized organizations are characterized by the existence of a single owner of the institution assisted by some helpers. Thus, most of the decisions and strategic focus is done or carried out by one person.

2- Informality: The prevailing relations inside the small-sized organizations are based on the spirit of friendship and family and informal relationships.

3- Locality: Most operations in small-sized organizations in a particular geographic area, means that its operations centers at a local site.

4- Successful Organizations Rely on Specialization: These organizations adopt and specialize in producing only one product.

5. The Use of the Means of Production is Small and Less Expensive: This means that these organizations do not use sophisticated techniques. They depend on the density unions, and lower production volume reduces storage costs (Najjar\& Ali, 2010).

\section{Financing of Small Projects}

There are several sources of Financing for small projects, including:

1-Private Funds to the Owner: Any saving money gotten from the private wealth of the employer relies on the ability of the owner to save money depending on the project size.

2- Borrowing from Friends and Family: Here, they lend money on favorable terms and conditions without any problems.

3. Commercial Banks: Banks are lending institution, and the bank demands for interest to be paid for guarantees and warranties to ensure repayment.

4. Specialized Organizations Supporting Small Projects in Jordan: There are many agencies that lend to small projects, such as the Development and Employment Fund, the Agricultural Credit Corporation, National Aid Fund, and the Jordanian company to secure loans (Bernouti, 2005). Table 1 shows the growth in the deposits at banks in Jordan.

Table 1. The growth in the deposits at banks in Jordan

\begin{tabular}{ll}
\hline Banking Deposits( m) & Year \\
\hline 11564.100 & 2004 \\
13119.300 & 2005 \\
14591.900 & 2006 \\
15988.100 & 2007 \\
18102.600 & 2008 \\
20298.400 & 2009 \\
22504.800 & 2010 \\
24377.900 & 2011 \\
24969.700 & 2012 \\
29159.92 & 2013 \\
31942.122 & 2014 \\
\hline
\end{tabular}

(The Annual Report of the Central Bank of Jordan, 2014)

\section{Importance of small projects:}

The small projects play an important role in the economy as follows:

1- The small projects create jobs and a lot of studies indicate to about $50 \%$ from jobs of economy, 
2- Increase the gross domestic product.

3- The basis for the big industries and organizations where it need the small projects in a lot of activities.

4-The basis for the development of creator and innovations (Read ,abedalsalam,shada \&aljaosi,2001).

\subsection{Previous Study}

There are many studies that addressed the Obstacles of finance of small projects. The most important of these studies are:

1- The Study (Aljuivel, 2013) entitled "The role of Islamic banks in the financing of small and medium-sized projects Jordanian." The study aimed to identify the role of Islamic banks in the financing of small and medium projects. Thus, the sample used in this study is the Jordan Islamic Bank and the Islamic International Arab Bank. The study shows the role of Islamic banks in the financing of small and medium-sized projects and the presence of obstacles facing banks in the financing of small and medium projects size.

The researcher recommended the establishment of Islamic banks to support the work of economic feasibility studies for projects to be funded. In addition, it provides new funding formulas suitable for small projects.

2- The Study (Buhaisi, 2006) entitled 'towards modern methods of financing small projects in the Gaza Strip." The study aimed to assess the current funding methods of small projects in the Gaza Strip and their ability to keep pace with the needs of these projects. Thus, this are considered to be the backbone of the Palestinian economy. The study found that many of the investors in the Gaza Strip are facing financial problems when implementing their projects. Also, the high Interest of the obtained finance by the banks is the most import ant obstacles facing small projects. Furthermore, the study suggested the establishment of a fund to finance small projects in the sector.

3- The Study (Almahroug\& al Magabla, 2006) entitled "Small projects and medium importance and constraints." The study aimed to identify the reality of small projects in developing countries, particularly with regard to access to financing. Thus, this is regarded as a big problem for small projects. The study found that an increase in the cost of the finance provides the guarantees required by banks for funding. The study recommended that there is need to provide a mechanism to ensure these loans are provided by banks. Also, the role of specialized lending institutions that provide financing for these projects should be activated.

4-The Study (Omar, Ballmosa, 2013) entitled "Obstacles for small and medium projects in Algeria and ways of developing." The study aimed to identify the problems and obstacles that are facing small and medium projects in Algeria and ways of support. The study identifies the importance of these institutions in the economic development of the national economy. It also pointed that some of the Asian countries have made tremendous achievements over the past period through its reliance on small projects.

The researcher recommended that there is a need to address the problems faced by these projects and there is the need to provide the needed infrastructure for such projects.

5- The Study (Alsawi, Ali, 2015) entitled "The role of the banks in the sustainability of micro-financing projects to address societal poverty." The Study aimed to identify the role of the banks in the sustainability of microfinance to alleviate societal poverty. Here lies the problem of the research in the non-exploitation of banks in Sudan to the proportion of $12 \%$ set by the Central Bank of Sudan. This was obtained from the portfolio of funding for financing smaller projects. The study found that no banks deal with this ratio's commitment due to low yield and the high cost of finance. The study recommended that there is a need to encourage banks to grant funding for small projects with state support for banks through tax exemptions.

6- The Study (Alsutan, 2007) entitled "the impact of the funding in the efficiency of small projects." The problem of this study is the lack of capital provided by the founders of small projects to fund operations. In contrast, institution of finance does not lend these projects which had a problem in finance. The study relied on a descriptive approach and analysis of data obtained from different sources. Also, questionnaires on50 small projects were distributed.

\section{Study Method}

\subsection{Methodology of the Study}

In this study, the hypotheses were tested, and an answer to the questions of the study was provided. The study relied on descriptive and analytic method, as well as field study. With regard to the descriptive method, the study gave an accurate picture of the Obstacles of financing small projects. Through previous studies, as for the side of the field, the study relied on a questionnaire designed to collect the necessary data to test hypotheses. 


\subsection{The Population of the Study: Scope of the Study}

The population of this study represents the Jordanian commercial banks in the Jordan, which offers various banking services to the customers. Here, the study distributed a questionnaire to obtain information about the study. Therefore, the sample of the study is the upper and middle level of employees in the Jordanian Commercial Banks distributed as shown in Table 2 below:

Table 2. Distribution of the Jordanian commercial banks

\begin{tabular}{llll}
\hline Bank & Assets & Rank & The ratio of total assets \\
\hline Arab bank & 8726 & 1 & $20.16 \%$ \\
Jordan Ahli bank & 2120 & 5 & $4.9 \%$ \\
Cairo Amman Bank & 1885.22 & 6 & $4.36 \%$ \\
Bank of Jordan & 1859.6 & 7 & $4.3 \%$ \\
The housing Bank & 6508.6 & 2 & $15.04 \%$ \\
Jordan Kuwait Bank & 2369 & 3 & $5.47 \%$ \\
Arab Jordan investment Bank & 1632 & 9 & $3.77 \%$ \\
Jordan Commercial bank & 1096.41 & 10 & $2.53 \%$ \\
Invest bank & 788.62 & 13 & $1.8 \%$ \\
Arab banking corp./Jordan & 1083 & 11 & $2.5 \%$ \\
Union bank & 2239.69 & 4 & $5.17 \%$ \\
Society general bank & 867.13 & 12 & $2 \%$ \\
Capital bank & 1825.47 & 8 & $4.22 \%$ \\
\hline
\end{tabular}

(Annual Report of the Association of Banks in Jordan, 2014)

Table 3. Distribution of questionnaire

\begin{tabular}{lll}
\hline Bank & No. of questionnaire & No. of obtained questionnaire \\
\hline Arab bank & 50 & 47 \\
Jordan Ahli bank & 15 & 15 \\
Cairo Amman Bank & 13 & 13 \\
Bank of Jordan & 13 & 13 \\
The housing Bank & 40 & 38 \\
Jordan Kuwait Bank & 10 & 10 \\
Arab Jordan investment Bank & 13 & 13 \\
Jordan Commercial bank & 6 & 6 \\
Invest bank & 5 & 5 \\
Arab banking corp./Jordan & 6 & 6 \\
Union bank & 15 & 13 \\
Society general bank & 6 & 6 \\
Capital bank & 13 & 13 \\
\hline S.J & \multicolumn{2}{c}{} \\
\hline
\end{tabular}

5.3 Tools of the Study

The researcher distributed designed a questionnaire to solicit the views of an employee of Jordanian commercial banks about the study through Likert scale. The study distributed 205 questionnaire, 198 of the questionnaire has been recovered, while the percentage is $96.5 \%$.

\subsection{Sincerity and Persistence of the Study Tool}

A tool of the study (a questionnaire) has been shown on a group of arbitrators (5 experts). To ensure the veracity of content resolution, good drafting, and representation of the subject accurately, the reliability coefficient of the questionnaire according to the coefficient (Cronbach alpha) is $83 \%$. This was performed through the statistical analysis of the study's sample.

\section{The Resul ts of Hypothesis Testing}

\subsection{Descriptive Statistics}

This section which contains the results of the study aimed to know the Obstacles of financing small projects. It also included a description of the personality variables for members of the study sample. In addition, the study used the Statistical Package for Social Sciences software (SPSS) to extract the averages, arithmetic, and standard deviations of the paragraphs of the questionnaire. Thus, the following is a presentation of the demographic variables according to Table 4 . 
Table 4. Distribution of the study sample according to demographic variables

\begin{tabular}{|c|c|c|}
\hline Variable & Frequency & Percentage $\%$ \\
\hline \multicolumn{3}{|l|}{ 1- Gender } \\
\hline Male & 149 & $75.2 \%$ \\
\hline Female & 49 & $24.8 \%$ \\
\hline \multicolumn{3}{|l|}{ 2- Job site } \\
\hline$\overline{\text { Manager }}$ department & 11 & $5.4 \%$ \\
\hline Assistant manager of the & 10 & $5 \%$ \\
\hline \multicolumn{3}{|l|}{ Department } \\
\hline Manager branch & 130 & $65.6 \%$ \\
\hline Head department & 47 & $24 \%$ \\
\hline \multicolumn{3}{|l|}{ 3-Academic Qualifications } \\
\hline$\overline{\text { Graduates (Ph.D. or Master) }}$ & 35 & $18 \%$ \\
\hline Bachelor's & 139 & $70 \%$ \\
\hline Diploma or less & 24 & $12 \%$ \\
\hline \multicolumn{3}{|l|}{ 4-Years of experience } \\
\hline 5 years or less & 8 & $4 \%$ \\
\hline More than 5 to10 years & 12 & $6 \%$ \\
\hline More than 10 to 15 years & 151 & $76 \%$ \\
\hline More than 15 years & 27 & $14 \%$ \\
\hline
\end{tabular}

6.2 Results of Testing the Hypotheses

\subsubsection{Descriptive Statistics}

Table 5. The results of the answers to the questions of the hypothesis

\begin{tabular}{|c|c|c|c|}
\hline Number & $\begin{array}{l}\text { Paragraph } \\
\text { Banking obstacles }\end{array}$ & $\begin{array}{l}\text { Arithmetic } \\
\text { Averages }\end{array}$ & $\begin{array}{l}\text { Standard } \\
\text { Deviations }\end{array}$ \\
\hline $1-$ & $\begin{array}{l}\text { The Commercial Bank apply high-interest rates on loans for the small } \\
\text { projects }\end{array}$ & 3.65 & .31 \\
\hline $2-$ & The term of loans of small projects is not suitable. & 3.22 & 1.09 \\
\hline $3-$ & $\begin{array}{l}\text { The Commercial Bank has required guarantees from the small projects in } \\
\text { order to approve the finance. }\end{array}$ & 3.61 & .59 \\
\hline $4-$ & $\begin{array}{l}\text { The amount of the granted loans from the Commercial Bank to small } \\
\text { projects is inadequate }\end{array}$ & 3.15 & 0.91 \\
\hline \multirow[t]{2}{*}{$5-$} & $\begin{array}{l}\text { The Commercial Bank does not allow the provision of non-funded term } \\
\text { on the small projects. }\end{array}$ & 3.13 & .75 \\
\hline & Total & 3.352 & \\
\hline
\end{tabular}

The researcher notes from the previous Table 5 includes paragraphs that test the first hypothesis that the Arithmetic Averages ranged between 3.15-3.65, and the highest average is paragraph No. 1, which states "The Commercial Bank apply high-interest rates on loans for the small projects." In general, all averages were higher than Class 3, and the overall average of banking obstacles is 3.352 .

Table 6. The results of the answers to the questions of the hypothesis

\begin{tabular}{|c|c|c|c|}
\hline Number & $\begin{array}{l}\text { Paragraph } \\
\text { Obstacles of the small projects }\end{array}$ & $\begin{array}{l}\text { Arithmetic } \\
\text { Averages }\end{array}$ & $\begin{array}{l}\text { Standard } \\
\text { Deviations }\end{array}$ \\
\hline 6- & $\begin{array}{l}\text { Management of the small projects doesn't have enough experience to } \\
\text { manage the project. }\end{array}$ & 3.51 & 1.16 \\
\hline 7- & $\begin{array}{l}\text { The small projects don't have administrative human resources that } \\
\text { possess the necessary skills. }\end{array}$ & 3.67 & 0.9 \\
\hline 8- & The products produced by small projects had low quality. & 3.18 & .91 \\
\hline 9- & There is a weakness in the marketing of small project's products. & 3.30 & .78 \\
\hline $10-$ & The products of small projects cannot compete in the market. & 3.40 & .71 \\
\hline $11-$ & $\begin{array}{l}\text { There is a weakness in the ability of small projects to repay their } \\
\text { obligations to commercial banks for the lack of sales. }\end{array}$ & 3.41 & .59 \\
\hline
\end{tabular}

The researcher notes from the previous Table 6, which includes paragraphs that test the first hypothesis that the Arithmetic Averages ranged between 3.18-3.67, and the highest average is paragraph No. 7, which states "The small projects don't have administrative efficiencies that possess the necessary skills." In general, all averages were higher than Class 3 , and the overall average of obstacles of small projects is 3.411.

Table 7. The results of the answers to the questions of the hypothesis 


\begin{tabular}{|c|c|c|c|}
\hline Number & $\begin{array}{ll}\text { Paragraph } & \\
\text { Governmental } \quad \text { obstacles }\end{array}$ & $\begin{array}{l}\text { Arithmetic } \\
\text { Averages }\end{array}$ & $\begin{array}{l}\text { Standard } \\
\text { Deviations }\end{array}$ \\
\hline $12-$ & Procedures of registration of small projects are long and complex. & 3.33 & .37 \\
\hline $13-$ & $\begin{array}{l}\text { There are no instructions and the laws of the central bank stimulate } \\
\text { commercial banks to finance small projects. } 13 \text {. }\end{array}$ & 3.45 & 1.01 \\
\hline 14- & There is a weakness in government laws that support small projects. & 3.88 & .57 \\
\hline $15-$ & $\begin{array}{l}\text { The government does not provide the necessary support to small } \\
\text { projects with regard to the training of human resources. }\end{array}$ & 3.34 & .83 \\
\hline 16- & $\begin{array}{l}\text { The government does not provide the necessary support for small } \\
\text { projects regarding the making of the economic feasibility study. } \\
\text { Total }\end{array}$ & 3.31 & .37 \\
\hline
\end{tabular}

The researcher notes from the previous table 7, which includes paragraphs that test the first hypothesis that the Arithmetic Averages ranged between 3.31-3.88, and the highest average is paragraph No. 14, which states "There is a weakness in government laws that supports small projects." In general, all averages were higher than Class 3 , and the overall average of the Governmental obstacles is 3.462 .

Table 8 . The results of answers to the questions of the hypothesis

\begin{tabular}{llll}
\hline Number & $\begin{array}{l}\text { Paragraph } \\
\text { Finance of the commercial bank to small projects }\end{array}$ & $\begin{array}{l}\text { Arithmetic } \\
\text { Averages }\end{array}$ & $\begin{array}{l}\text { Standard } \\
\text { Deviations }\end{array}$ \\
\hline $17-$ & $\begin{array}{l}\text { The Commercial banks are reluctant to grant funding for small projects } \\
\text { because weak cash flows in small projects. }\end{array}$ & 3.39 & .92 \\
$18-$ & $\begin{array}{l}\text { The Commercial banks have tightened the application of safeguards } \\
\text { because of the poor credit worthiness in small projects. }\end{array}$ & 3.38 & .21 \\
$19-$ & $\begin{array}{l}\text { The Commercial banks give small projects suitable amounts because } \\
\text { of poor creditworthiness. }\end{array}$ & 3.31 & .79 \\
$20-$ & $\begin{array}{l}\text { Some of the reasons of refusing the commercial banks to lend small } \\
\text { projects are poor management and lack of experience. }\end{array}$ & 3.12 & .23 \\
$21-$ & $\begin{array}{l}\text { Some of the reasons of refusing the commercial banks to lend small } \\
\text { projects are weak cash flows and the absence of economic feasibility } \\
\text { study. }\end{array}$ & 3.88 & 3.416 \\
& Total & & \\
\hline
\end{tabular}

The researcher notes from previous Table 8 , which includes paragraphs that test the first hypothesis that the Arithmetic Averages ranged between 3.12-3.88, and the highest average is paragraph No. 21, which states "Some of the reasons of refusing the commercial banks to lend small projects are weak cash flows and the absence of economic feasibility study." In general, all averages were higher than Class 3, and the overall average of the Finance of the commercial bank to small projects is 3.416.

\subsubsection{Test of the First Hypotheses}

In the section of this study, we present an analysis of the results of the study hypotheses. As mentioned before, in testing Ho1, we also use a sample of an employee of the Jordanian commercial banks. The following subsections provide an analysis of the results of hypotheses testing at the total sample level.

In testing the first hypothesis, multiple linear regression tests was used and the result is as shown in Table 9.

Ho1 - There is no significant statistical impact of the obstacles (Banking obstacles, small projects obstacles, Governmental obstacles) on the financing of small projects at $\mathrm{p} \leq 0.05$

Table 9. Result of the multiple linear regression tests

\begin{tabular}{|c|c|c|c|c|}
\hline $\begin{array}{l}\text { Dependent Variable } \\
\text { Financing of small projects }\end{array}$ & Independent Variables & Regression Coefficient B & Value of T calculated & Sig. \\
\hline \multirow{3}{*}{ Financing of small projects } & Banking obstacles & 0.151 & 2.01 & 0.002 \\
\hline & small projects obstacles & 0.107 & 1.32 & 0.003 \\
\hline & Governmental obstacles & 0.071 & 1.24 & 0.001 \\
\hline $\mathrm{R} 2=0.7744$ & & Sig. $=0.000$ & & \\
\hline
\end{tabular}

From Table 9, there is a significant impact of independent variables on the dependent variable. Thus, this refers to the good relation between Affecting Factors and the financing of small projects, the value of Sig. is less than 0.005 , and The value of Pearson correlation $(\mathrm{R})=0.88$. Thus, this refers to the rejection of the null hypothesis and the acceptance of the alternative hypothesis.

To test the sub-hypothesis no.(1), we used a simple linear regression test and the result is as shown in Table 10. Ho1-1 - There is no significant statistical impact of the Banking obstacles on the financing of small projects at $\mathrm{p}$ $\leq 0.05$.

Table 10. Result of the simple linear regression test 


\begin{tabular}{lllll}
\hline Independent Variable & Dependent Variable & Regression Coefficient B & Value of T calculated & Sig. \\
\hline Financing of small projects & Banking obstacles & 0.123 & 1.70 & 0.002 \\
$\mathrm{R}=0.84$ & $\mathrm{R} 2=0.7056$ & $\mathrm{~F}=57.1$ & Sig. $=0.002$ \\
\hline
\end{tabular}

From the Table 10, there is a significant impact of the independent variable on the dependent variable. Thus, this refers to the good relation between the Banking obstacles and the financing of small projects, the value of Sig. less than 0.05 , and the value of Pearson correlation $(\mathrm{R})=0.84$. This refers to the rejection of the null hypothesis and acceptance of the alternative hypothesis.

To test the sub-hypothesis no (2), we used a simple linear regression test and the result is as shown in Table 11.

Ho1-2. There is no significant statistical impact of the Small Projects obstacles on the financing of small projects at $\mathrm{p} \leq 0.05$

Table 11. Result of the simple linear regression test

\begin{tabular}{lllll}
\hline Independent Variable & Dependent Variable & Regression Coefficient B & Value of T calculated & Sig. \\
\hline Financing of small projects & small projects obstacles & 0.121 & 2.57 & 0.001 \\
$\mathrm{R}=0.81$ & $\mathrm{R} 2=0.6561$ & $\mathrm{~F}=44.1$ & & Sig. $=0.001$ \\
\hline
\end{tabular}

From Table 11, there is a significant impact of the independent variable on the dependent variable. Thus, this refers to the good relation between small projects obstacles on the financing of small projects, the value of Sig. less than 0.05 , and the value of Pearson correlation $(R)=0.81$. This refers to the rejection of the null hypothesis and the acceptance of the alternative hypothesis.

In testing the sub-hypothesis no (3), we used simple linear regression test and the result as shown in Table 12.

Ho1-3 - There is no significant statistical impact of the Governmental obstacles on the financing of small projects at $\mathrm{p} \leq 0.05$.

Table 12. Result of the simple linear regression test

\begin{tabular}{llllc}
\hline Independent Variable & Dependent Variable & Regression Coefficient B & Value of T calculated & Sig. \\
\hline Financing of small projects & Governmental obstacles & 0.144 & 1.60 & .003 \\
$\mathrm{R}=0.83$ & $\mathrm{R} 2=0.6889$ & $\mathrm{~F}=44.1$ & & Sig. $=0.003$ \\
\hline
\end{tabular}

From the table 12, there is a significant impact of the independent variable on the dependent variable. Thus, this refers to the good relation between Governmental obstacles on the financing of small projects, the value of Sig. less than 0.05 , and the value of Pearson correlation $(\mathrm{R})=0.83$. This refers to the rejection of the null hypothesis and the acceptance of the alternative hypothesis.

\section{Summary and Conclusion}

This study attempts to investigate the impact of the obstacles (Banking obstacles, small projects obstacles, and Governmental obstacles) on the financing of small projects. Thus the results (findings) show:

1 - There is a significant statistical impact of the obstacles (Banking obstacles, small projects obstacles, Governmental obstacles) on the financing of small projects from Jordanian commercial banks.

2-The study rejected the null hypotheses and accepted the alternative hypotheses for the main hypotheses.

3-The study rejected the null hypothesis and accepted the alternative hypothesis for the three sub-hypothesis.

4- There is a good statistical relationship between the obstacles (Banking obstacles, small projects obstacles, Governmental obstacles) and the financing of small projects from Jordanian commercial banks.

\section{Recommendations}

The study has recommended the following:

1. The Central Bank should make laws that force banks to set aside a portion of the loans portfolio to small projects.

2. There is a need for the government to support to small projects; specifically training of the human resources and the making of an economic feasibility study.

3. There is a need for the government to provide support to small projects with respect to the establishment of institutions to ensure that small projects also obtain financing. 
Abdullah, K. A., \&Trad, I. (2006). Manage demotic and international banking operations.1st edition, Amman, Jordan: Dar Wael for publication, 32.

Aljuivel, M. S. I. (2013). The role of Islamic banks in the Jordanian finance facilities for small and medium-sized. Master thesis, the University of the Middle East, Amman, Jordan.

Almahroug, M., \& Al-Magabla, E. (2006). Small projects and medium importance and constraints small and medium-sized Publications Center, Arab Academy for Banking and Financial Sciences, Amman, Jordan.

Alsawi, A. bloAbd Ali, \& Qasi, M. (2015). The role of the banks in the sustainability of micro-financing projects to address societal poverty. Journal of Economic Sciences, 15(1).

Alsultan, H. (2009). The impact of the funding in the efficiency of small projects. Master publication, the University of Damascus, Syria.

Association of Banks in Jordan. (2014). Annual report of the Association of Banks in Jordan in 2014. Retrieved from : http://www.abj.org.jo/en-us/annualreports.aspx

Bernouti, S. N. (2005). The Small Business Administration, Dar Wael for Publishing and Distribution, Amman, Jordan, 273-276.

Buhaisi, E. M. (2006). Towards modern methods of financing small projects in the Gaza Strip. In The Second Scientific Conference Faculty of Commerce, The Islamic University, Development \& Improvement of Gaza Strip after the Israeli Withdrawal 13-15 February 2006, , Gaza, Palestine

Central Bank of Jordan. (2015). Annual Report of the Central Bank of Jordan in 2015. Retrieved from: http://www.cbj.gov.jo/

Najjar, F. J. S., \& Ali, M. A. (2010).The leadership and the Small Business Administration. 2ed edition: Dar Al-Hamed for Publishing and Distribution, Amman, Jordan, (80-86).

Omar, A., \& Ballmosa, A. (2013). Obstacles for small and medium projects in Algeria and ways of developing. In a Scientific conference titled: reality and prospects of financial accounting system for small and medium projects in Algeria, the University of the Wadi, Algeria.

Read, A., abedalsalam, A., shada, H., \& aljaosi, M. (2001). Small project management, safa for publishing, Amman, Jordan, 9-10.

\section{Copyrights}

Copyright for this article is retained by the author(s), with first publication rights granted to the journal.

This is an open-access article distributed under the terms and conditions of the Creative Commons Attribution license (http://creativecommons.org/licenses/by/4.0/). 